\title{
Examination of the Individual Competencies that Differentiate Results in Direct Sales
}

\author{
Barbara A. Sypniewska ${ }^{1}$
}

ABSTRACT

The importance of knowledge and skills in meeting new challenges in production and distribution is particularly evident in today's market, which is characterized by a saturation of products and strong competition. To be successful in the market, companies must stand out and be creative and communicative. The leading factor in providing these features is the human potential, which represents both opportunities and threats to the operation and development of the companies. For companies involved in sales, especially direct sales, this factor is expressed in the specific competencies of individual employees. The importance of individual competence in direct sales is reflected in the demand for research in this field.

This article presents the results of research the author conducted on a group of 455 direct sales vendors that operate in the form of direct sales known as multilevel marketing (MLM). The respondents represented three groups: group I - inexperienced sellers that are starting work; group II - sellers who reach significant sales results; and group III - the leaders that achieve the highest sales results. The article presents the results of two analyses, namely discriminant and correlation analysis. The purpose of the discriminant analysis was to identify the set of competencies that particularly distinguish each group. The analysis was performed to indicate the factors that differentiate the surveyed groups. The purpose of the correlation analysis was to identify the correlation between particular competencies in the surveyed groups. Intercorrelations between the individual competencies were analyzed. The results identified the competences that best differentiate the surveyed sellers groups and also showed that most competencies strongly correlate with one another. The results indicate that by influencing the development of one competency, another set of competencies can be developed. This is an important aspect of the development of training programs for sellers.

KEY WORDS: $\quad$ individual competencies, direct sales, multilevel marketing, discriminant analysis, correlation analysis

JEL Classification: M12, M21, M31, M53, M54, J24, J30, J44

1 University of Finance and Management in Warsaw, Poland

\section{Introduction}

Manufacturers search for different sales solutions. This results in changes in the methods of distribution, a reㅁ duction in distribution channels and a reduction in the

Correspondence concerning this article should be addressed to: Agata Barbara Sypniewska, University of Finance and Management in Warsaw, 55 Pawia Str., 01-030 Warsaw, Poland, e-mail: agata.sypni@op.pl distance that a product has to "overcome". To encourage the customer to buy a particular product, companies attract them with an attractive price, a special offer or more a convenient form of purchase. One of these forms is direct sales.

To be successful in the market, companies have to know how convince the customer to purchase the product. Therefore, there is competition for the customer in which some win and some lose, but not everyone 
can achieve permanent supremacy. This supremacy is related not only to the "best idea" but also to a competent seller that can identify the client and keep them interested for a longer time. The ability to sell products under competitive market conditions is a key factor that leads to success. The ability to sell is closely associated with the competencies of the salesperson. These competencies include such qualities as knowledge and skills, which are visible external elements, as well as hidden elements such as values, motives and attitudes (Ludwiczyński, 2002, pp. 283-299). The visible external components are easier to shape through various forms of training, while the hidden components are much more difficult to assess and change (Pocztowski, 2001, p. 169). The skills are interrelated in the sense that the development of some may affect the development of others (Rakowska, 2002, p. 23). Previous studies emphasize that the mere acquisition of a particular skill is not enough to ensure that the employee is competent because factors such as readiness, willingness/motivation and the use of the skill or knowledge are indispensable (Rakowska \& Sitko-Lutek, 2000, p. 17). For an employee or manager to be considered competent, they should interpret their knowledge and skills for effective action (Antonacopoulou \& Fitzgerald, 1996, p. 28). Competencies are considered to be employees' abilities to use their knowledge in specific professional situations. Therefore, competencies can be defined as knowledge, experience, attitude and willingness to work in various conditions and the ability to adapt to changing conditions (Thierry, Sauret \& Monod, 1994, p. 173). Competence thus carries an element of causative power.

Competencies are more than having knowledge, skills and attitudes; the ability to use them is required to achieve the desired results. Competencies are not just personal attributes. They are the result of the relationship between experience and practice (Olle, Snell \& Carraccio, 2010, pp. 670-671).

When defining individual competencies, many authors draw attention to their influence on executing tasks during professional work. In this perspective, competencies may mean professional abilities (knowledge, skills, experience, attitudes) that are recognized as potential opportunities for different activities or in relation to a current position. Competencies therefore have social, technical and conceptual aspects (Louart, 1995, p. 228).
Some authors suggest that individual competencies include education, experience, proficiency, talents, abilities, and behavior that is expected by the employer and is important in professional work (Oleksyn, 1997, p. 4). Competencies may also include fixed sets of knowledge, skills, and ways of thinking that can be applied without additional learning (Levy-Leboyer, 1997, p. 19). Moreover, competencies are related to the ability to apply skills and knowledge to new situations within a profession (Rakowska \& Sitko-Lutek, 2000, p. 17). Knowledge that helps someone operate effectively should also be transferred from the sender (e.g., trainer) in such a way that the recipient increases his abilities, which in turn leads to an increase of work so that the organization can achieve its goals (Wang \& Haggerty, 2009, p. 579).

Individual competencies are recognized as permanent features that lead to high or above average work results (Pocztowski \& Miś, 2000, p. 69). All of the components of competence (personality, knowledge, skills and values) are associated with work in such a way as to perform tasks (Armstrong, 2000, p. 242) that affect the work of the individual (Becker, Huselid \& Ulrich, 2002, p. 162) and allow the worker to perform these tasks well at a specific and appropriate level (Ludwiczyński, 2006, p. 231-274).

The meanings of the concepts of highest efficiency, outstanding or good results and an appropriate level in terms of competence should be considered in relation to efficiency. These concepts are used in the literature as effectiveness, productivity, efficiency and proficiency, which are concepts that define the goals that the organization sets for the employee. In addition, the increasing competitiveness of companies leads organizations to observe, identify and target the effects while taking into account the human resources that they currently have, need and will need in the future.

An interesting approach of how to define individual competencies is recognizing their use as a source of corporate success and in achieving planned strategies and business goals. In this perspective, components of competency (knowledge, skills, abilities, styles of working, personality, valued principles, interests) that are used and developed in the work process lead to results that are compatible with the strategic goals of the organization (Rostkowski, 2002, p. 66). In this way, the concept of individual competencies assumes the use of any char- 

- interpersonal competencies - the ability to understand people and influence their behavior. These competencies include such activities as communication, leadership and motivation (Listwan, 1995,

pp. 22-23).

One of the first divisions of competencies was made by R.L. Katz, who divided competencies into technical, interpersonal and conceptual abilities. Technical abilities include knowledge of methods, techniques, procedures, and the ability to use special tools related to a particular discipline. Interpersonal abilities include knowledge of human behavior and their relationships and the ability to understand feelings, attitudes, motivation, whereas conceptual abilities are general analytical abilities, logical thinking, creativity, deductive thinking, and anticipating effects and changes (Katz, 1955, pp. 33-42).

According to R. L. Katz, the levels of specific abilities possessed by a manager is dependent on the level of management. At lower levels of management, technical abilities are most important. Interpersonal abilities become more important at average levels of management but are important at all levels. Conceptual abilities are most significant at higher levels of management. Of course, it is important to have and use all kinds of abilities at the highest level, but the most significant abilities are a global way of thinking and the ability to coordinate and recognize the organization as a whole (Stoner, Freeman \& Gilbert, 1999, p. 33).

Some researchers believe that defining competencies may be consistent not only with our intuition (colloquial understanding) but also with the psychological knowledge of the mechanisms that determine high competencies or lack of them. Other important factors are whether one's mental dispositions are correlated with smooth operation of a particular position and which ones can play the most important roles in this process (Nosal, 1999, p. 90).

Therefore, we adopt the following definition of individual competencies for the purposes of our studies. Individual competencies are knowledge, attitudes, skills, willingness to act and a set of personality traits and predispositions that lead to superior results when used. The division of competencies is consistent with the analysis of managerial competencies, including technical, conceptual, and interpersonal competencies, but their use depends on the level of management.
This is reasonable because of the proposed thesis that people at the highest level of sales are characterized by more specific skills than those that are inexperienced and are starting their career. The three levels of management may not be completely equivalent to the three levels of the effects of work (sales results) that form the three groups in this research. However, there are some similarities because it is a collection of competencies that take into account the specific requirements of the various management levels and different levels of salespeople. The most important competencies in the work of the President or Chief Executive Officer are often unimportant in the case of the lowest-level manager, and vice versa. The same assumption can be made when analyzing groups of salespeople in multilevel marketing; that is, the most important competency for a manager with the highest sales (group III) is not necessarily relevant for entry-level salespeople (group I).

Direct sales is considered to be the oldest channel of distribution. In the Middle Ages, direct sales dealers were called "bagmen" or "peddlers". They contributed to the development of trade by moving goods from one location to another and presenting them to wider ranges of customers. At the beginning of the twentieth century, direct sales played particularly important roles for products that required appropriate presentations of the ways to use them. For example, the vacuum cleaner, which was technically a new product, had to be adequately demonstrated before it could be sold. Currently, direct sales is a booming business sector that gives millions of people around the world the opportunity to run their own businesses and earn a living.

Many subject experts define direct sales as all sales that take place outside of stores, including agents of the company that visit potential customers at their homes or places of work and present goods, samples or catalogs to them (Czubala, 2001, p. 83).

The World Federation of Direct Selling Associations (WFDSA) and the European Direct Selling Association consider direct sales as providing consumer goods and services directly to customers through personal contact, usually in their homes, workplaces or other locations that are not regular points of sale. The advantage of this type of sale for the buyer is the opportunity to see and test the product at any time, at home or among friends. Goods are delivered directly to the customer (www.wfdsa.org; www.fedsa.be). 

stores. Direct selling has also become an alternative to traditional employment because it is a flexible way to earn and increase household income. It is an excellent form of running a business because it creates opportunities for personal and career development (www. wfdsa.org). However, in the case of fraudulent manufacturers, there is a risk that sellers will have to cover the indirect costs associated with distribution, promotion or returned goods when the manufacturer does not accept them from the seller. It should also be noted that direct selling does not guarantee stability of employment. Sellers cooperate with manufacturers on the basis of civil law contracts, and the generated salary is based on commission and depends only on the seller's sales. In addition, the seller bears high initial financial and time costs that are required to find potential customers.

For businesses, direct sales provide an advantage because they do not have to create their own retail networks. However, the disadvantages of this type of business include the high costs of training salespeople and the loss of control over the selling of goods.

Direct sales can be used for any product, but it is particularly important for products that are subject to larger risks. Risks can be associated with the product, its price, the terms and conditions of purchase, the buyer experience, and the quantity and quality of the products. The role of the seller is closely linked with that risk because the seller's personality and attitude can address the buyer's doubts and concerns. The contribution of the salesperson is essential and irreplaceable when selling products such as electronic equipment, household appliances, cosmetics, and foreign travel. The more expensive the goods are, the higher the buyer's risk is; the seller's role is to provide information about the product to reduce the buyer's risk and increase the chance of a sale (Altkorn, 1999, p. 330).

One form of direct selling is multilevel marketing (MLM), which began in the 1940s in the USA. The first products offered under this system were cleaning products. This form has evolved over time, and more diverse goods have been offered for sale. The first company that introduced multilevel marketing in Europe is the Kleeneze Homecare Company, which was founded in 1969. After some time, multilevel marketing began to develop dynamically in Europe and worldwide. Companies using MLM offered a wide range of prod- ucts and services in a way that mainly generated positive feelings in buyers. Studies have shown that in sales, psychological factors associated with social ties that are caused by personal contact with the customer are very important (Vander Nat \& Keep, 2002, p. 140).

A typical feature of multilevel marketing is bidirectionality of the operation:

1. personal direct sales of goods and services and their advertising, which involves selling products or services directly to customers (Sparks \& Schenk, 2001, p. 851).

2. sponsorship, which is the introduction of other people interested in starting a business and joining the group of sellers. The companies reward sponsors for recruiting and training new members according to rules defined in the marketing plans (Garbarski, Rutkowski \& Wrzosek, 2008, p. 473).

The different definitions of multilevel marketing demonstrate that it differs from other forms of selling in several respects:

- it does not use wholesalers or retailers and does not have costs associated with storage, processing, financing and marketing research. Most of the costs of distribution are covered by the distributors from the trade margin;

- the distribution costs paid by the distributors are lower than traditional costs because they do not include advertising, maintenance of a sales department, or logistics (Buss, 1997, p. 47);

- sales involve the skillful building of long-lasting personal relationships with a client and require a large amount of time and attention to be paid to the customer. The profit comes from the quantity of goods sold, the number of sellers involved in the system (network) and the level of their sales.

The essence of multilevel marketing is the opportunity to build your own business enterprise (Garbarski, Rutkowski \& Wrzosek, 2008, p. 473). By running the business, the distributors own and develop their own company without much risk or high costs. The seller is an independent partner of the manufacturer who operates on his own behalf in his own business. This differs from an employee of a traditional company, where the seller is only a hired employee. Distributors can earn more by recruiting additional distributors than from current sales of products or services (Goldsborough, 2001, p. 15). In multilevel marketing, it is possible to differentiate 

operate with a particular company, and an additional question that classifies the surveyed person by level (starting out in the business - group I, coordinators group II, leaders - group III).

The operationalization of competencies during the competency selection process led to a questionnaire that originally contained 63 questions. Each competency was described with a number of questions, and a five-grade Likert scale was used for the answers (Frankfort-Nachmias \& Nachmias, 2001, p. 479). A pilot study was then conducted. The results were analyzed statistically using the Cronbach Alpha test, which checks the accuracy of the tool. Based on these results, another verification of the research tool was performed by removing 16 questions. After the pilot study, the research tool included 47 questions. After the actual study was conducted, the testing tool using the Cronbach Alpha method was repeated. The results confirmed the accuracy of the tool.

The pilot survey covered the period from January to April 2007, while the actual survey covered the period from June 2007 to December 2008. The study included 455 salespeople representing four companies that operate on a multilevel marketing basis. The sellers came from across Poland and were divided into three groups based on the size of their community: less than 100,000 inhabitants, from 100,000 to 500,000 inhabitants and more than 500,000 inhabitants. The choice of respondents was random, but the respondents were equally distributed across the groups. Respondents were assigned to a group based on the marketing plans developed by each of the surveyed companies. The marketing plans include principles of cooperation and remuneration and are specific for each company. These principles are related to the amount of turnover that the individual sellers and their networks obtain. Each person was assigned to a particular research group (effects levels) based on the percentage of turnover and their position according to the marketing plan.

The structure of the groups was as follows:

group I or effects level 1 - inexperienced salespeople who are just starting in the business; their effects on sales (e.g., turnover volume) are negligible;

- group II or effects level 2 - coordinators who have already achieved significant sales but do not have the highest sales; group III or effects level 3 - leaders who achieve the highest results in multilevel marketing sales.

People at the levels of coordinator and leader ran their own businesses on the principles of the self-employment. Few individuals at level 1 were not self-employed. Cooperation with the companies was based on the distribution contract (civil - legal agreement).

The study identified the following research problems:

1. Are the competency profiles for the different effects levels similar?

2. What set of competencies determines the achievement of certain levels of sales?

3. What competencies do not influence the results of the lower effects levels?

4. Do characteristic competencies appear at particular levels?

5. What competencies are common to all effects levels?

6. Does the importance (intensity) of particular competencies increase at the higher effects levels?

7. What are the specific competencies in multilevel marketing sales?

8. Is there a set of competencies that distinguishes different effects levels from each other?

The main research hypothesis was formulated as follows: individual competencies of salespeople influence the results of direct sales. It is assumed that multilevel marketing is a form of direct selling.

In addition, the following hypotheses were formulated:

I. The volumes of sales in multilevel marketing are subject to a specific set of competencies of the salespeople.

II. A particular set of competencies becomes important at higher effects levels and influences these effects on sales in multilevel marketing.

III. There is a common set of competencies for all effects levels.

IV. There is a set of specific competencies for sales in multilevel marketing.

V. There is a characteristic set of dominant competencies for each effects level.

VI. There is a set of competencies that particularly distinguishes the effects levels from each other.

To verify the hypotheses, people at different effects levels were studied based on the previously described survey. 
Table 1. Standardized ratios of canonical discriminant functions

\begin{tabular}{ccc}
\hline Competencies & \multicolumn{2}{c}{ Function } \\
\cline { 2 - 3 } & 1 & 2 \\
\hline Entrepreneurship & 0.20 & -0.26 \\
Customer orientation & -0.05 & -0.14 \\
Strategic thinking & 0.12 & 0.14 \\
Supporting the development & 0.04 & -0.03 \\
Interpersonal communication & -0.14 & -0.12 \\
Leadership & $\mathbf{0 . 4 2}$ & -0.23 \\
Leading a team & $\mathbf{0 . 3 6}$ & -0.08 \\
Self-motivation & -0.13 & $\mathbf{0 . 8 4}$ \\
Attitudes to work & -0.15 & 0.19 \\
Dealing with stress & -0.11 & $\mathbf{0 . 9 6}$ \\
Knowledge and experience & $\mathbf{0 . 3 7}$ & -0.08 \\
Learning & 0.11 & $\mathbf{0 . 9 1}$ \\
\hline
\end{tabular}

\section{The results of research}

This article presents the results of analyses that were intended to verify the hypotheses described above. The analysis shows that a set of individual competencies distinguishes the effects levels in multilevel marketing from each other. In addition, the results were analyzed to determine possible linear relationships between the variables. The r-Pearson test (Jóźwiak \& Podgórski, 2000, pp. 370 - 376; Ścibor-Rylski, 2007, pp. 95-97) was used for this purpose.

\section{Discriminant analysis}

Discriminant analysis was performed to analyze the data in terms of the factors that differentiate the groups. The discriminant analysis tries to create a linear combination of independent variables that best "discriminate" (separate) two or more groups. The analysis can be performed by finding estimators that maximize intergroup variability in relation to intragroup variability. To do this, a discriminant function that finds the "direction in space" that best separates the group data is created. The accuracy of the discriminant function is tested by estimating the corresponding ratio of correctness after applying this function to a known group. The ratio accuracy is also defined, which in turn is a measure of how well the discriminant function separates the analyzed groups.
Twelve tested competencies were included as explanatory variables for the discriminant analysis, in which the grouping variable belonged to the three analyzed groups. The Wilks' Lambda indicator, which shows how many discriminant functions should be used, was calculated. The Wilks' Lambda values showed two statistically significant discriminatory features: $\lambda=0.92$ and $\chi^{2}=36.71, \mathrm{p}<0.001$. The analysis showed that the two discriminatory functions that differentiate between the three surveyed groups have been highlighted.

The first function explained $89.1 \%$ of the variance, while the second explained $10.9 \%$ of the variance. These values show the extent to which functions 1 and 2 differentiate the groups. The first function is more important because it differentiates groups to a greater extent. The mere distinction of the number of functions of the research reasons is insufficient; the competencies that are included in functions 1 and 2 must be determined. Standardized ratios of the canonical discriminant function were calculated for this purpose. The values of these ratios are shown in Table 1.

The standardized canonical ratios of the discriminant functions that provide the essential saturation of a function with a particular competence are greater than 0.30 . They are shown in Table 1 in bold (column 1 - function 1). The values indicate that the first factor 


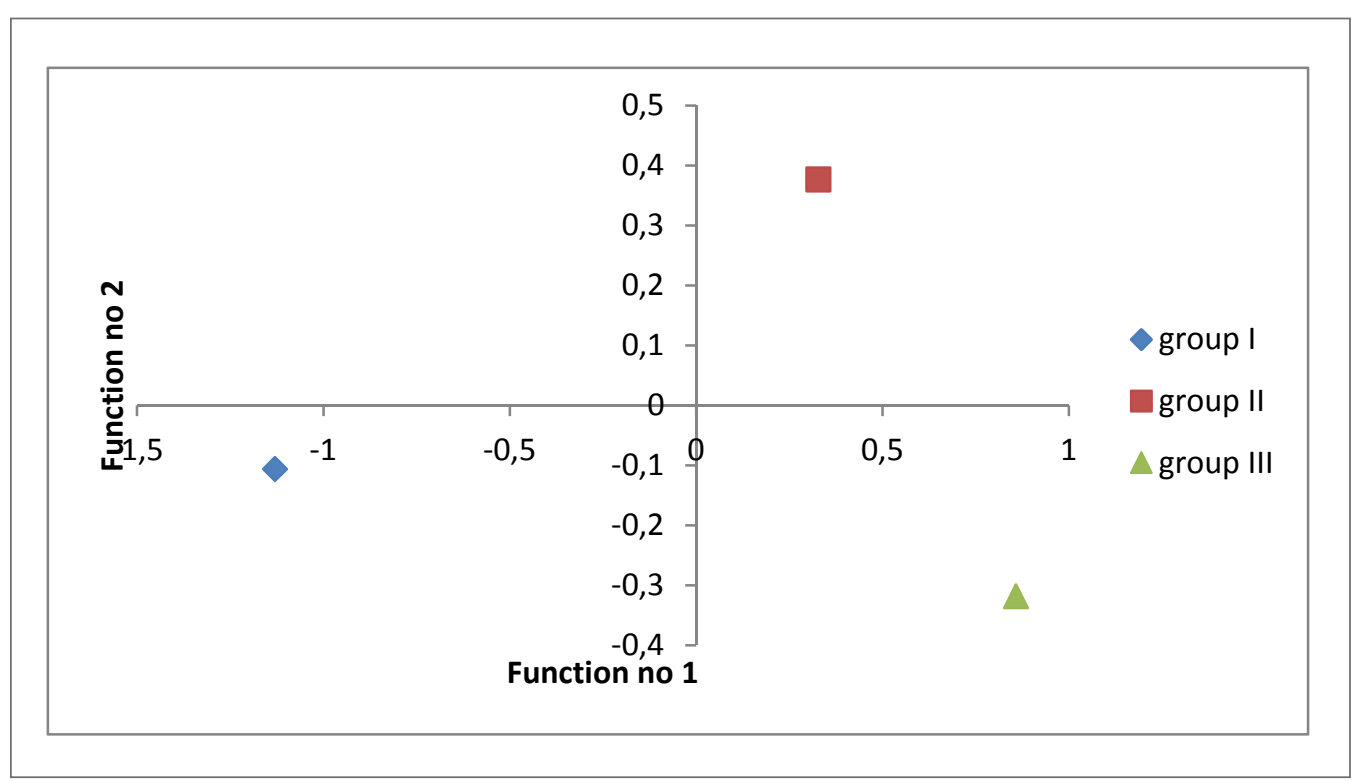

Figure 1. Discriminant functions in the centers of gravity of groups

that differentiates groups is function 1 , which can be interpreted as a combination of leadership, team management, knowledge and experience. Function 2 should be interpreted as the level of self-motivation, learning and the difference between the level of these two competencies and the level of dealing with stress. A negative value appeared in the case of function 2 , which indicates that differences between one's own motivation, learning and dealing with stress separates the groups. To best illustrate the distribution of the standardized canonical ratios of the two discriminant functions ( 1 and 2) that differentiate the three surveyed groups, they should be presented as a graph that indicates the center of gravity of the groups. The values of the discriminant functions in the centers of gravity of the groups are shown in Figure 1. The values of these rates are shown in bold in column 2 of Table 1 (function 2).

The discriminant analysis showed that:

- Function No. 1, which includes the level of leadership, team management, knowledge and experience, best differentiates group I from group II and group III.

- Function No. 2 best differentiates groups II and III. Group III has smaller proportions of motivation, learning and dealing with stress than group II.

It therefore can be concluded that:
1. The discriminant analysis showed that competencies such as leadership, team management, knowledge and experience most differentiate group I from groups II and III. These competencies are stronger in groups II and III than in the group I, which is composed of people who have just started selling in multilevel marketing.

2. The discriminant analysis also showed that the differences in proportions between the competencies of self-motivation, learning and coping with stress most differentiate group II from group III. The difference between the groups is not related to higher levels of these competences but rather to the differences in their proportions. Groups II and III include sellers that have already achieved significant results in sales.

\section{Correlation analysis - correlations between individual competencies in the surveyed groups}

The statistical analysis of the data indicated the need for additional analysis that is focused on the connections and relationships between competencies. Thus, a correlation analysis was used to determine the intercorrelations between the individual competencies and the different effects levels (groups I, II, and III). The correlation 
Table 2. Correlation matrixes between the competences for three groups of respondents determined by the effects level

\section{Group I correlations (r Pearson)}

\begin{tabular}{|c|c|c|c|c|c|c|c|c|c|c|c|c|}
\hline & 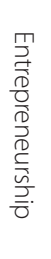 & 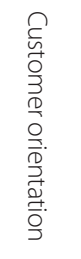 & 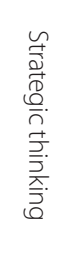 & 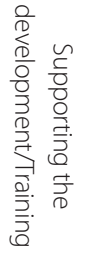 & 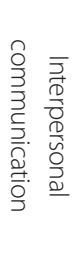 & $\begin{array}{l}\frac{1}{D} \\
\stackrel{N}{O} \\
\frac{D}{D} \\
\frac{N}{N} \\
\frac{D}{0} .\end{array}$ & 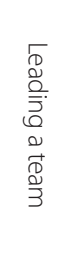 & 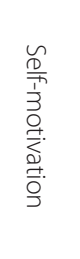 & 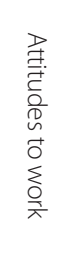 & 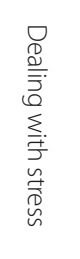 & 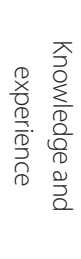 & $\begin{array}{l}\frac{5}{D} \\
\frac{2}{3} \\
\frac{5}{6}\end{array}$ \\
\hline Entrepreneurship & 1 & 0.779 & 0.827 & 0.837 & 0.808 & 0.823 & 0.796 & 0.688 & 0.76 & 0.882 & 0.791 & 0.846 \\
\hline Customer orientation & & 1 & 0.777 & 0.714 & 0.711 & 0.665 & 0.675 & 0.566 & 0.634 & 0.64 & 0.715 & 0.713 \\
\hline Strategic thinking & & & 1 & 0.838 & 0.796 & 0.815 & 0.8 & 0.639 & 0.712 & 0.797 & 0,793 & 0.787 \\
\hline $\begin{array}{l}\text { Supporting the } \\
\text { development/training }\end{array}$ & & & & 1 & 0.825 & 0.865 & 0.805 & 0.659 & 0.699 & 0.79 & 0.725 & 0.78 \\
\hline $\begin{array}{l}\text { Interpersonal } \\
\text { communication }\end{array}$ & & & & & 1 & 0.858 & 0.805 & 0.698 & 0.732 & 0,793 & 0.759 & 0.792 \\
\hline Leadership & & & & & & 1 & 0.879 & 0.742 & 0.77 & 0.855 & 0.749 & 0.798 \\
\hline Leading a team & & & & & & & 1 & 0.749 & 0.723 & 0.804 & 0.762 & 0.755 \\
\hline Self-motivation & & & & & & & & 1 & 0.651 & 0.676 & 0.67 & 0.644 \\
\hline Attitudes to work & & & & & & & & & 1 & 0.84 & 0.707 & 0.744 \\
\hline Dealing with stress & & & & & & & & & & 1 & 0.764 & 0.84 \\
\hline $\begin{array}{c}\text { Knowledge and } \\
\text { experience }\end{array}$ & & & & & & & & & & & 1 & 0.781 \\
\hline Learning & & & & & & & & & & & & 1 \\
\hline
\end{tabular}

Note

White color indicates significance at the level $p<0.001$;

Numbers in bold indicate significance at the level $p<0.001$;

Dark grey color with bold letters indicates significance at the level $p<0.001$;

Light grey color indicates an insignificant correlation. 
Table 2. (continued)

\section{Group II correlations ( $r$ Pearson)}

\begin{tabular}{|c|c|c|c|c|c|c|c|c|c|c|c|c|}
\hline & 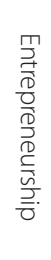 & 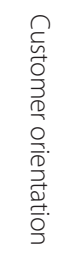 & 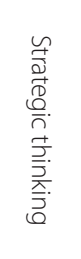 & 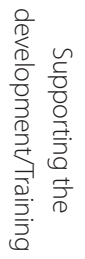 & 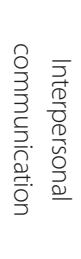 & 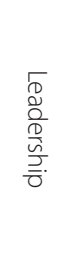 & 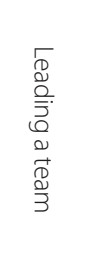 & 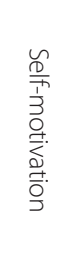 & 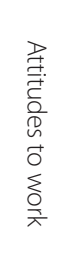 & 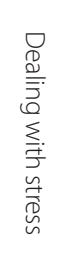 & 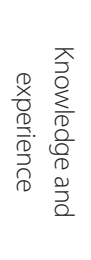 & 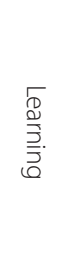 \\
\hline Entrepreneurship & 1 & 0.543 & 0.498 & 0.348 & 0.56 & 0.472 & 0.228 & 0.344 & 0.425 & 0.586 & 0.162 & 0.23 \\
\hline Customer orientation & & 1 & 0.462 & 0.356 & 0.44 & 0.412 & 0.103 & 0.307 & 0.404 & 0.495 & 0.159 & 0.272 \\
\hline Strategic thinking & & & 1 & 0.55 & 0.475 & 0.6 & 0.479 & 0.416 & 0.345 & 0.521 & 0.388 & 0.447 \\
\hline $\begin{array}{c}\text { Supporting the } \\
\text { development/training }\end{array}$ & & & & 1 & 0.364 & 0.638 & 0.575 & 0.173 & 0.039 & 0.321 & 0.171 & 0.46 \\
\hline $\begin{array}{l}\text { Interpersonal } \\
\text { communication }\end{array}$ & & & & & 1 & 0.478 & 0.268 & 0.436 & 0.412 & 0.538 & 0.329 & 0.379 \\
\hline Leadership & & & & & & 1 & 0.515 & 0.395 & 0.21 & 0.552 & 0.338 & 0.425 \\
\hline Leading a team & & & & & & & 1 & 0.295 & 0.034 & 0.27 & 0.232 & 0.313 \\
\hline Self-motivation & & & & & & & & 1 & 0.485 & 0.401 & 0.394 & 0.293 \\
\hline Attitudes to work & & & & & & & & & 1 & 0.473 & 0.195 & 0.153 \\
\hline Dealing with stress & & & & & & & & & & 1 & 0.241 & 0.347 \\
\hline $\begin{array}{l}\text { Knowledge and } \\
\text { experience }\end{array}$ & & & & & & & & & & & 1 & 0.435 \\
\hline Learning & & & & & & & & & & & & 1 \\
\hline
\end{tabular}

Note

White color indicates significance at the level $p<0.001$;

Numbers in bold indicate significance at the level $p<0.001$;

Dark grey color with bold letters indicates significance at the level $p<0.001$;

Light grey color indicates an insignificant correlation. 
Table 2. (continued)

\section{Group III correlations (r Pearson)}

\begin{tabular}{|c|c|c|c|c|c|c|c|c|c|c|c|c|}
\hline & 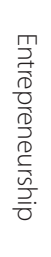 & 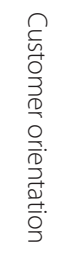 & 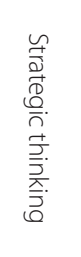 & 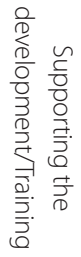 & 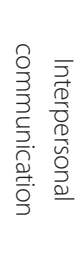 & $\begin{array}{l}\frac{1}{D} \\
\frac{O}{0} \\
\frac{D}{D} \\
\frac{N}{0} \\
\frac{D}{0} .\end{array}$ & 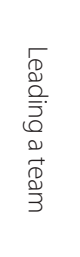 & 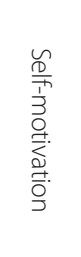 & 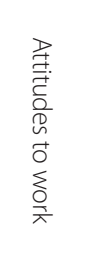 & 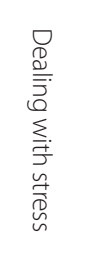 & 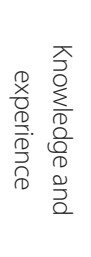 & 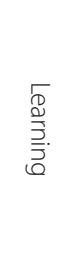 \\
\hline Entrepreneurship & 1 & 0.297 & 0.432 & 0.335 & 0.379 & 0.428 & 0.335 & 0.142 & 0.198 & 0.369 & 0.155 & 0.147 \\
\hline Customer orientation & & 1 & 0.353 & 0.491 & 0.415 & 0.299 & 0.161 & 0.223 & 0.274 & 0.261 & 0.215 & 0.114 \\
\hline Strategic thinking & & & 1 & 0.588 & 0.374 & 0.45 & 0.462 & 0.24 & 0.228 & 0.279 & 0.214 & 0.192 \\
\hline $\begin{array}{c}\text { Supporting the } \\
\text { development/training }\end{array}$ & & & & 1 & 0.472 & 0.51 & 0.491 & 0.386 & 0.304 & 0.19 & 0.31 & 0.274 \\
\hline $\begin{array}{l}\text { Interpersonal } \\
\text { communication }\end{array}$ & & & & & 1 & 0.328 & 0.349 & 0.233 & 0.367 & 0.356 & 0.208 & 0.208 \\
\hline Leadership & & & & & & 1 & 0.503 & 0.424 & 0.388 & 0.39 & 0.158 & 0.206 \\
\hline Leading a team & & & & & & & 1 & 0.128 & 0.283 & 0.267 & 0.165 & 0.129 \\
\hline Self-motivation & & & & & & & & 1 & 0.446 & 0.274 & 0.183 & 0.136 \\
\hline Attitudes to work & & & & & & & & & 1 & 0.452 & 0.265 & 0.154 \\
\hline Dealing with stress & & & & & & & & & & 1 & 0.278 & 0.31 \\
\hline $\begin{array}{l}\text { Knowledge and } \\
\text { experience }\end{array}$ & & & & & & & & & & & 1 & 0.562 \\
\hline Learning & & & & & & & & & & & & 1 \\
\hline
\end{tabular}

Note

White color indicates significance at the level $p<0.001$;

Numbers in bold indicate significance at the level $p<0.001$;

Dark grey color with bold letters indicates significance at the level $p<0.001$;

Light grey color indicates an insignificant correlation.

analysis was performed by examining the relationships between variables to determine how the two variables change. The correlation strength is measured by a correlation indicator, which is expressed as a numerical value between -1 and +1 (Aczel, 2000, pp. 479-480). Higher correlations indicate a greater influence of one variable on another (Bielecka, 2005, p. 276).

The correlation analysis of all of the competencies identified various intercorrelations. The results indicate positive correlations with different strengths between 0 
and 1 . This means that if one of the competencies has a high value (close to 1 ), the second tested competency also has a high value. Conversely, when the value of one variable decreases, the value of the other variable also decreases (Aczel, 2000, p. 480). Table 2 shows the correlation matrices corresponding to the three surveyed groups.

The correlation analysis of all of the competencies showed that most of the competencies strongly correlate with each other (this also confirms the reliability of the research tool, which was calculated for all questions from the questionnaire). It is interesting that in group I, all competencies correlate with each other at the highest level of significance, but certain combinations are not significant in the other groups. For example, four competency pairs in group I lost significance in group II, while eleven pairs lost significance in group III. Several other combinations also have lower levels of significance.

The correlation analysis showed that there is a strong correlation between the competencies in group I, which indicates that changing or developing one competency will also develop another competency. Such a strong correlation does not exist in groups II and III. Correlation therefore answers the question of whether interacting with one competency will change another.

The in-depth statistical analysis showed that group I has the most diverse set of competencies. There are statistically significant differences between groups I, II and III in all twelve competencies. The largest increase of competencies is between groups I and II. However, the discriminant analysis provided additional details about which competencies most differentiate these groups. Comprehensive statistical analysis of intragroup comparisons showed that leadership and team management are the weakest competencies in group I, and there is a significant statistical difference between these competencies in groups II and III. Knowledge and experience are dominant competencies in all groups. The analyses of intra-group and inter-group comparisons shows the distribution of these competencies in relation to each other and the groups, and the discriminant analysis allows us to formulate additional conclusions about the most important factors that distinguish the groups from each other.

The results of the discriminant analysis concerning the disparities between the self-motivation, learning and dealing with stress competencies, as well as the results of the comprehensive statistical analysis, indicated that there are no significant statistical differences in the case of learning and self-motivation and that the average values in groups II and II are similar. Therefore, these qualities do not differentiate the two groups. In addition, there is no difference between self-motivation and dealing with stress in group III, but there is a difference in group II. In this case, the dealing with stress competency is lower. A significant statistical difference occurs between learning and dealing with stress in group III; the difference is small but is larger than in group II. Therefore, it can be concluded that the difference in group III is smaller than that in group II.

In summary, group II mostly differs from group III not in the intensity of the individual competencies (some of the differences are statistically significant, while some are not) but in that group II deals worse with stress than group III, despite the high levels of some competencies. Group II has a similarly high level of self-motivation as group III. The results indicate that competencies in groups II and III are at a similar level, but the average competency of dealing with stress is much lower in group III than in group II. Thus, group III (the group of individuals achieving the highest sales) has a high concentration of competencies and also deals better with stress. Group II also has a high concentration of competencies but deals worse with stress. People in group II are motivated; they want to learn but do not deal effectively with difficult situations because of tensions, conflicts, failures or time pressure, which can affect the quality of their work.

All of the groups generally deal poorly with stress, so the lack of this competency is a common feature for all three groups of respondents. This feature may be typical of the work of the seller. This phenomenon may be counteracted by appropriate training and workshops that enhance mental resistance to failure and difficult situations. However, this fact should be taken into account and investigated in further research conducted on this topic.

A large decrease in self-motivation was observed in group III. This may be caused by several factors, including professional burnout, but it may also have been caused by disappearance the meaning of one of the tested competencies (e.g., need for achievements, power and belonging). Therefore, this issue is recommended as a topic for future studies. 

Hypothesis 5. There is a set of characteristic dominant competencies for given effects levels. This hypothesis was verified positively.

The statistical analysis showed that there was a statistically significant interactive effect between belonging to one of the three professional groups and the different levels of individual competencies: F (17.99, $4057.31)=15.87, \mathrm{p}<0.001$

Hypothesis 6. There is a set of competencies that particularly distinguishes the effects levels from each other. This hypothesis was verified positively using discriminant analysis.

The analysis also showed that there are positive correlations between all of the competencies with varying strengths of dependences. Most of the competencies strongly correlate with each other, which means that developing one competency will influence the development of a different one or a set of other competencies.

\section{Refernces}

Aczel, A. (2000). Statystyka w zarzadzaniu [Statistics in management]. Warszawa: PWN.

Altkorn, J. (Ed.). (1999). Podstawy marketingu [Fundamentals of Marketing]. Kraków: Instytut Marketingu.

Antonacopoulou, E., Fitzgerald, L. (1996). Framing Competency in Management Development. Human Resource Management Journal, 6(1), 27-48.

Armstrong, M. (2000). Zarządzanie zasobami ludzkimi [Human Resource Management]. Kraków: Dom Wydawniczy ABC.

Armstrong, M. (2004). Zarządzanie zasobami ludzkimi [Human Resource Management]. Kraków: Oficyna Ekonomiczna.

Becker, B. E., Huselid, M. A., Ulrich, D. (2002). Karta wyników zarzadzania zasobami ludzkimi [The scorecard of human resource management]. Kraków: Oficyna Ekonomiczna.

Bielecka, A. (2005). Statystyka $w$ biznesie i ekonomii: teoria i praktyka [Statistics in Business and Economics: Theory and practice]. Warszawa: Wydawnictwo Wyższej Szkoły Przedsiębiorczości i Zarządzania im. Leona Koźmińskiego.

Buss, D.D. (1997). A direct route to customers. Nation's Business, 85(September), 46 - 50.
Czubała, A. (2001). Dystrybucja produktów [Distribution of products]. Warszawa: PWE.

Dewandre, P., Mahieu, C. (1997). Przyszłość marketingu wielopoziomowego $w$ Europie. Racje sukcesu MWP [The future of multi-level marketing in Europe. MLM success reasons]. Szczecin: Horizon International.

Fletcher, C. (2002). Ocena pracy: ewaluacja i doskonalenie potencjału pracowników i ich pracy [Evaluation of the work: the evaluation and improvement of the potential of employees and their work]. In N. Chmiel (Ed.), Psychologia pracy i organizacji [Psychology of work and organization] (pp. 145 - 168). Gdańsk: Gdańskie Wydawnictwo Psychologiczne.

Frankfort-Nachmias, C., Nachmias, D. (2001). Metody badawcze $w$ naukach społecznych [Research methods in the social sciences]. Poznań: Zysk i S-ka.

Garbarski, L., Rutkowski, I., Wrzosek, W. (2008). Marketing. Punkt zwrotny nowoczesnej firmy [Marketing. The turning point of modern business]. Warszawa: PWE.

Goldsborough, R. (2001). Making Money with Your PC. Community College Week, 13(17), 15 - 20.

Hawley, L. A. \& Newman, J. K. (2010). Group interactive structured treatment (GIST): A social competence intervention for individuals with brain injury. Brain Injury, 24(11), 1292 -1297.

Jóźwiak, J., Podgórski, J. (2000). Statystyka od podstaw [Principles of Statistics]. Warszawa: PWE.

Katz, R. L. (1955). Skills of an effective administrator. Harvard Bussines Review, Jan/Febr, 33 - 42.

Król, H. (2002): Czynnik ludzki w organizacji [The human factor in the organization]. In H. Król (Ed.), Szkice z zarzadzania zasobami ludzkimi [Essays in human resource management] (pp. 1 - 25). Warszawa: Wydawnictwo Wyższej Szkoły Przedsiębiorczości i Zarządzania im. Leona Koźmińskiego.

Król, H. (2006). Podstawy koncepcji zarządzania zasobami ludzkimi [Fundamentals of human resource management concepts]. In H. Król \& A. Ludwiczyński (Eds.), Zarządzanie zasobami ludzkimi. Tworzenie kapitału ludzkiego organizacji [Human Resources Management. Building the organization's human capital] (pp. 50 - 91). Warszawa: PWN.

Lee, B. (2003). Talking on the level about multilevel marketing. San Diego Business Journal, 18(12), 37 - 39. 
Levy-Leboyer, C. (1997). Kierowanie kompetencjami. Bilanse doświadczeń zawodowych [Directing competencies. Balances of professional experiences]. Warszawa: Poltext.

Listwan, T. (1995). Kształtowanie kadry menedżerskiej firmy [Shaping the managers of the company]. Wrocław: KADRY.

Louart, P. (1995). Kierowanie personelem $w$ przedsiębiorstwie [Staff management in the company]. Warszawa: Poltext.

Ludwiczyński, A. (2002). Kryteria oceny pracy menedżera personalnego [Criteria for evaluation of personnel manager]. In H. Król (Ed.), Szkice z zarządzania zasobami ludzkimi [Essays in human resource management] (pp. 283 - 299). Warszawa: Wydawnictwo Wyższej Szkoły Przedsiębiorczości i Zarządzania im. Leona Koźmińskiego.

Ludwiczyński, A. (2006). Wartościowanie pracy [Valuation of work]. In H. Król \& A. Ludwiczyński (Eds.), Zarzadzanie zasobami. Tworzenie kapitału ludzkiego organizacji. [Resources Management. Building the organization's human capital] (pp. 231 - 274). Warszawa: PWN.

Nosal, C. (1999). Psychologia decyzji kadrowych [Psychology of human resources decisions]. Kraków: Wydawnictwo Profesjonalnej Szkoły Biznesu.

Oleksyn, T. (1997). Praca i płaca w zarządzaniu [Job and salary in management]. Warszawa: Międzynarodowa Szkoła Menedżerów.

Olle, T. J., Snell, L., Carraccio, C. (2010). Medical competence: the interplay between individual ability and the health care environment. Medical Teacher, 32(8), $669-675$

Pocztowski, A., Miś, A. (2000). Modelowanie kompetencji kierowniczych $\mathrm{w}$ aspekcie kreowania kapitału ludzkiego w organizacji [Modeling managerial competencies in terms of the creation of human capital in the organization]. In B. Kożuch (Ed.), Kształtowanie kapitału ludzkiego firmy [Shaping the capital of the company] (pp. 67 - 77). Białystok: Uniwersytet w Białymstoku.

Pocztowski, A. (2001). Wokół pojęcia kompetencji i ich znaczenia w zarządzaniu zasobami ludzkimi [Around the concept of of competencies and its importance in human resource management]. In In B. Urbaniak (Ed.), Gospodarowanie praca
[Management of work] (pp. 165 - 174). Łódź: Wydawnictwo Uniwersytetu Łódzkiego.

Pocztowski, A. (2007). Zarządzanie zasobami ludzkimi [Human Resource Management]. Warszawa: PWN.

Rakowska, A., Sitko-Lutek, A. (2000). Doskonalenie kompetencji menedżerskich [Improvement of managerial competencies]. Warszawa: PWN.

Rakowska, A. (2002). Zrozumieć aby kierować. Umiejętności współczesnego menedżera [Understand to manage. Skills of modern manager]. Personel i Zarządzanie, 3(120), 24 - 25.

Rostkowski, T. (2002). Zarządzanie kompetencjami jako przyszłość zzl w Polsce [Competency Management as the future of HRM in Poland]. Zarzadzanie zasobami ludzkimi, 6, 65 - 76 .

Sajkiewicz, A. (1999). Człowiek - kreator wartości przedsiębiorstw [The man - the wizard of companies value]. In A. Herman \& A. Szablewski (Eds.), Zarządzanie wartością firmy [Company Value Management] (pp. 73 - 100). Warszawa: Poltext.

Sparks, J., Schenk, J. (2001). Explaining the effects of transformational leadership: an investigation of the effects of higher-order motives in multilevel marketing organizations. Journal of Organizational Behavior, 22(8), 849 - 869.

Sparrow, P. (1997). Organizational competencies: Creating a strategic behavioural framework for selection and assessment. In N. Anderson \& P. Herriot (Eds.), International Handbook of Selection and Assessment. Chichester, UK: John Wiley \& Sons Inc.

Spencer, L. M., Spencer, S. M. (1993). Competence at Work. Models for Superior Performance. New York, NY: John Wiley and Sons Inc.

Stoner, J. A. F., Freeman, R. E., Gilbert, D. R. (1999). Kierowanie [Management]. Warszawa: PWE.

Strykowska, M. (2000). Poczucie dezaktualizacji kierowniczej [A sense of management obsolescence]. In S. Witkowski (Ed.), Acta Universitatis Wratislaviensis no 2240 [series]. Prace Psychologiczne: Psychologiczne wyznaczniki sukcesu $w$ zarzadzaniu [Psychological determinants of success in management]: Vol. 5. (pp. 33 - 43). Wrocław: Wydawnictwo Uniwersytetu Wrocławskiego.

Ścibor-Rylski, M. (2007). Miary związku pomiędzy zmiennymi- współczynnik korelacji [Measures 
of the relationship between variables-correlation indicator]. In S. Bedyńska \& A. Brzezicka (Eds.), Statystyczny drogowskaz. Praktyczny poradnik analizy danych $w$ naukach społecznych na przykładach $z$ psychologii [Statistical signpost. A practical guide to data analysis in the social sciences, with examples from psychology] (pp. 95 115). Warszawa: Wydawnictwo Szkoły Wyższej Psychologii Społecznej "Academica”.

Thierry, D., Sauret, C., Monod, N. (1994). Zatrudnianie $i$ kompetencje $w$ przedsiębiorstwie $w$ procesach zmian [Employing and competencies in the company in the process of change]. Warszawa: Poltext.

Vander Nat, P. J, Keep, W. W. (2002). Marketing Fraud: An Approach for Differentioting Multilevel Marketing from Pyramid Schems. Journal of Public Policy and Marketing, 21(1), 139 - 151.

Wang, Y., Haggerty, N. (2009). Knowledge transfer in virtual settings: the role of individual virtual competency. Information Systems Journal, 19(6), $571-593$.

WFDSA (n.d.) What is Direct Selling? Retrieved from www.wfdsa.org

Woodruffe, C. (1996). Assessment Centres: Identifying and Developing Competence. London: Institute of Personnel and Development. 